\title{
Hubungan antara Mencuci Wajah dengan Kejadian Akne Vulgaris pada Remaja Laki-laki di Manado
}

\author{
Fifin R. T. Sole, ${ }^{1}$ Pieter L. Suling, ${ }^{2}$ Tara S. Kairupan ${ }^{2}$
}

\author{
${ }^{1}$ Program Studi Pendidikan Dokter Fakultas Kedokteran Universitas Sam Ratulangi Manado \\ ${ }^{2}$ Bagian Ilmu Kesehatan Kulit dan Kelamin Fakultas Kedokteran Universitas Sam Ratulangi \\ Manado \\ Email: fifinrerungtandisole@gmail.com
}

\begin{abstract}
Acne vulgaris is a chronic skin condition involving inflammation of the pilosebaceous follicle. The highest prevalence of acne vulgaris is at the age of 16-17 years. Pathogenic factors contributing to the development of acne vulgaris include increased sebum production, pilosebaceous follicular blockage, and increased colonization of Propionibacterium acnes. Personal hygiene is suggested as an important factor that needs to be maintained in acne prevention. Males tend to lack of awareness to seek information and health services in dealing with acne problems. This study was aimed to evaluate the relationship between facial washing and the incidence of acne vulgaris in adolescent males in Manado. This was an analytical and observational study using a cross-sectional design. Subjects were male students of 3rd grade at SMA Negeri 9 Manado, aged 16-19 years old, and met the inclusion and exclusion criteria, with a total number of 95 students. Subjects who washed their faces 2-3 times a day were 38 students $(40 \%)$ while those who washed their faces less than twice or more than thrice a day were 57 students $(60 \%)$. Subjects with no or mild acne vulgaris were 39 students $(41.1 \%)$, while those with moderate to severe acne vulgaris were 56 students (58.9\%). The chi-square showed a p-value of 0.004 for the relationship between the frequency of facial washing and the incidence of acne vulgaris. In conclusion, there was a significant relationship between facial washing and the incidence of acne vulgaris in adolescent males in Manado.
\end{abstract}

Keywords: facial washing, acne vulgaris

\begin{abstract}
Abstrak: Akne vulgaris merupakan peradangan kronis folikel pilosebasea dengan prevalensi tertinggi pada usia 16-17 tahun. Faktor yang memengaruhi terjadinya akne vulgaris antara lain peningkatan produksi sebum, penyumbatan folikel pilosebasea, dan peningkatan kolonisasi bakteri Propionibacterium acnes. Kebersihan diri merupakan faktor penting yang perlu dijaga sebagai salah satu usaha untuk mencegah timbulnya akne. Laki-laki cenderung kurang memiliki kesadaran untuk mencari informasi dan pelayanan kesehatan dalam menangani masalah akne. Penelitian ini bertujuan untuk menilai hubungan antara mencuci wajah dengan kejadian akne vulgaris pada remaja laki-laki di Manado. Jenis penelitian ialah observasional analitik dengan desain potong lintang. Subjek penelitian ialah siswa laki-laki kelas 3 di SMA Negeri 9 Manado, usia 16-19 tahun, dan memenuhi kriteria inklusi dan eksklusi, dengan jumlah total 95 siswa. Subjek yang mencuci wajah 2-3 kali sehari sebanyak 38 siswa (40\%) sedangkan yang mencuci wajah kurang dari 2 kali atau lebih dari 3 kali sehari sebanyak 57 siswa (60\%). Subjek tanpa akne vulgaris atau akne derajat ringan sebanyak 39 siswa $(41,1 \%)$ sedangkan yang dengan akne vulgaris derajat sedang sampai berat sebanyak 56 siswa $(58,9 \%)$. Uji chi-square memperlihatkan nilai $\mathrm{p}=0.004$ terhadap hubungan antara frekuensi mencuci wajah dengan kejadian akne vulgaris. Simpulan penelitian ini ialah terdapat hubungan bermakna antara mencuci wajah dengan kejadian akne vulgaris pada remaja laki-laki di Manado.
\end{abstract}

Kata kunci: mencuci wajah, akne vulgaris 


\section{PENDAHULUAN}

Jerawat atau dalam istilah kedokteran disebut dengan akne vulgaris merupakan peradangan kronis pada permukaan kulit dan biasa timbul pada daerah-daerah predileksi seperti wajah, bahu, dada, dan punggung yang berbentuk komedo, papul, pustul, nodus, dan/ atau kista. ${ }^{1}$ Akne vulgaris dimulai pada masa pubertas dengan insiden terbanyak pada perempuan berusia 14-17 tahun dan laki-laki berusia 16-19 tahun dengan prevalensi tertinggi pada usia 16-17 tahun. ${ }^{2}$ Meskipun tidak termasuk penyakit yang mengancam jiwa namun akne dapat menyebabkan gangguan psiko-sosial seperti tidak percaya diri dan cemas. ${ }^{3}$

Faktor-faktor penyebab akne meli-puti faktor intrinsik (genetik, ras. dan hormonal) dan faktor ekstrinsik (stres, iklim/ kelembaban, kosmetik, diet, dan obat-obatan). ${ }^{1}$ Selain faktor intrinsik dan ekstrinsik tersebut, saat ini faktor mencuci wajah mulai diteliti peranannya terkait timbulnya akne vulgaris.

Masa remaja merupakan masa transisi atau peralihan dari masa anak menuju masa dewasa. Setelah menginjak usia remaja, individu mulai harus bertanggung jawab untuk merawat dirinya sendiri. Di lain pihak, aktivitas fisik menjadi lebih padat dan cenderung lebih banyak kegiatan di luar ruangan. Kebersihan diri merupakan faktor penting yang perlu dijaga sebagai salah satu usaha untuk mencegah timbulnya akne. ${ }^{4}$ Peneliti memilih populasi laki-laki karena populasi ini cenderung kurang baik dalam memperhatikan kebersihan diri, sehingga meningkatkan kemungkinan timbulnya akne. Laki-laki juga cenderung kurang memiliki kesadaran untuk mencari informasi dan mencari pelayanan kesehatan dalam menangani masalah akne. ${ }^{5}$ Dibandingkan perempuan, populasi laki-laki dianggap lebih homogen karena kurangnya faktor-faktor ekstrinsik seperti peng-gunaan kosmetik dan produk perawatan wajah sehingga dianggap sebagai populasi penelitian yang tepat.

Berdasarkan latar belakang yang diuraikan di atas, penulis tertarik melakukan penelitian untuk mengetahui hubung- an antara mencuci wajah dengan akne vulgaris pada remaja di Manado.

\section{METODE PENELITIAN}

Penelitian ini dilaksanakan di SMA Negeri 9 Manado. Jenis penelitian yang digunakan yaitu observasional analitik dengan desain potong lintang. Subjek penelitian yaitu siswa laki-laki kelas 3 SMA, usia 16-19 tahun, dan memenuhi kriteria inklusi dan eksklusi. Penelitian ini dilakukan dengan menggunakan kuesioner untuk menilai frekuensi mencuci wajah dan pemeriksaan fisik langsung serta foto untuk menegakkan diagnosis akne vulgaris. Uji chi-square digunakan untuk menilai hubungan antara mencuci wajah dengan kejadian akne vulgaris pada remaja laki-laki di Manado.

Penelitian ini telah mendapat persetujuan dari Komisi Etik Penelitian Kesehatan RSUP Prof. Dr. R. D. Kandou Manado, dengan nomor keterangan layak etik yaitu No. 110/EC/KEPK-KANDOU/XII/2019.

\section{HASIL PENELITIAN}

Berdasarkan hasil penelitian diper-oleh subjek penelitian sebanyak 95 siswa yang memenuhi kriteria inklusi dan eksklusi. Hasil penelitian disajikan dalam bentuk tabel dan deskriptif.

Tabel 1 menampilkan distribusi kejadian akne vulgaris. Persentase tertinggi ialah subyek dengan akne ringan $(37,9 \%)$, diikuti akne sedang $(32,7 \%)$, dan akne berat $(26,3 \%)$; sedangkan persentase terendah ialah yang tidak memiliki akne $(3,1 \%)$.

Tabel 1. Distribusi kejadian akne vulgaris

\begin{tabular}{lll}
\hline Kejadian akne vulgaris & \multicolumn{2}{c}{ Total } \\
& n & \% \\
\hline Tidak ada & 3 & 3,1 \\
Ringan & 36 & 37,9 \\
Sedang & 31 & 32,7 \\
Berat & 25 & 26,3 \\
Total & 95 & 100 \\
\hline
\end{tabular}

Tabel 2 memperlihatkan subyek dengan frekuensi mencuci wajah 2-3x sehari sebanyak 71 orang $(74,8 \%)$, sedangkan 
yang kurang dari $2 \mathrm{x}$ sehari atau lebih dari $3 \mathrm{x}$ sehari sebanyak 24 orang $(25,2 \%)$

Tabel 2. Distribusi kejadian akne vulgaris

\begin{tabular}{lcc}
\hline \multicolumn{1}{c}{ Frekuensi } & \multicolumn{2}{c}{ Total } \\
mencuci wajah & n & \% \\
\hline 2-3x sehari & 71 & 74,8 \\
$<2 x$ atau $>3 x$ sehari & 24 & 25,2 \\
Total & 95 & 100 \\
\hline
\end{tabular}

Tabel 3 memperlihatkan subyek paling banyak berada pada usia 17 tahun (57 siswa). Persentase subyek dengan akne vulgaris berat paling banyak pada usia 16 tahun (32\%). Jenis kulit subyek paling banyak yaitu berminyak sebesar 68 siswa $(71,6 \%)$ dengan derajat akne berat sebanyak 21 siswa $(30,9 \%)$. Pencuci wajah yang paling banyak digunakan ialah facial foam sebanyak 58 siswa (61\%). Subyek yang memiliki anggota keluarga berjerawat sebanyak 63 siswa $(66,3 \%)$. Subyek yang mengonsumsi makanan berminyak, tinggi lemak dan protein sebanyak 81 siswa $(85,2 \%)$. Untuk pola tidur, subjek yang memiliki pola tidur baik sebanyak 22 siswa dan yang kurang baik sebanyak 73 siswa.

Tabel 4 menunjukkan subyek dengan frekuensi mencuci wajah 2-3x sehari berjumlah 71 orang $(74,7 \%)$, dan subjek yang mencuci wajah kurang dari $2 \mathrm{x}$ dan lebih dari $3 \mathrm{x}$ sehari berjumlah 24 orang $(25,2 \%)$. Dari 71 subjek yang mencuci wajahnya 2-3 kali sehari, terdapat 35 orang $(49,3 \%)$ tidak memiliki akne vulgaris atau hanya memiliki akne ringan, dan 36 orang (50,7\%) memiliki akne derajat sedang sampai berat. Di lain pihak, dari 24 subjek yang mencuci wajahnya kurang dari $2 \mathrm{x}$ sehari atau lebih dari $3 \mathrm{x}$ sehari, terdapat 4 orang $(16,7 \%)$ tidak memiliki akne vulgaris atau hanya memiliki akne ringan dan 20 orang $(83,3 \%)$ memiliki akne derajat sedang sampai berat.

Tabel 3. Karakteristik subyek menurut kejadian akne vulgaris

\begin{tabular}{|c|c|c|c|c|c|c|c|c|c|c|}
\hline \multicolumn{11}{|c|}{ Kejadian Akne vulgaris } \\
\hline & \multicolumn{2}{|c|}{ Tidak ada } & \multicolumn{2}{|c|}{ Ringan } & \multicolumn{2}{|c|}{ Sedang } & \multicolumn{2}{|c|}{ Berat } & \multicolumn{2}{|c|}{ Jumlah } \\
\hline & $\mathbf{n}$ & $\%$ & $\mathbf{n}$ & $\%$ & $\mathbf{n}$ & $\%$ & $\mathbf{n}$ & $\%$ & $\mathbf{n}$ & $\%$ \\
\hline \multicolumn{11}{|l|}{ Usia, tahun } \\
\hline 16 & 2 & 8,0 & 3 & 12,0 & 12 & 48,0 & 8 & 32,0 & 25 & 100 \\
\hline 17 & 8 & 14,0 & 19 & 33,3 & 23 & 40,3 & 7 & 12,2 & 57 & 100 \\
\hline 18 & 1 & 16,7 & 2 & 33,3 & 2 & 33,3 & 1 & 16,7 & 6 & 100 \\
\hline 19 & 1 & 14,3 & 3 & 42,9 & 1 & 14,3 & 2 & 28,6 & 7 & 100 \\
\hline Total & 12 & 12,6 & 27 & 28,4 & 36 & 37,9 & 20 & 21,1 & 95 & 100 \\
\hline \multicolumn{11}{|l|}{ Jenis kulit } \\
\hline Normal & 10 & 41,7 & 6 & 25,0 & 5 & 20,8 & 3 & 12,5 & 24 & 100 \\
\hline Kering & 1 & 33,3 & 0 & 0 & 2 & 66,7 & 0 & 0 & 3 & 100 \\
\hline Berminyak & 3 & 4,4 & 19 & 27,9 & 25 & 36,8 & 21 & 30,9 & 68 & 100 \\
\hline \multicolumn{11}{|c|}{ Pencuci wajah } \\
\hline Facial foam & 11 & 19,0 & 12 & 20,7 & 21 & 36,2 & 14 & 24,1 & 58 & 100 \\
\hline Sabun biasa & 5 & 8,6 & 11 & 19,0 & 12 & 20,7 & 9 & 15,5 & 37 & 100 \\
\hline \multicolumn{11}{|c|}{ Anggota keluarga berjerawat } \\
\hline $\mathrm{Ya}$ & 5 & 7,9 & 21 & 33,3 & 22 & 34,9 & 15 & 23,8 & 63 & 100 \\
\hline Tidak & 7 & 21,9 & 6 & 18,8 & 11 & 34,4 & 8 & 25,0 & 32 & 100 \\
\hline \multicolumn{11}{|c|}{ Konsumsi makanan berminyak, tinggi lemak dan protein } \\
\hline Ya & 13 & 16,0 & 21 & 25,9 & 25 & 30,9 & 22 & 27,2 & 81 & 100 \\
\hline Tidak & 3 & 21,4 & 2 & 14,3 & 6 & 42,9 & 3 & 21,4 & 14 & 100 \\
\hline \multicolumn{11}{|l|}{ Pola tidur } \\
\hline Ya & 7 & 31,8 & 5 & 22,7 & 6 & 27,3 & 4 & 18,2 & 22 & 100 \\
\hline Tidak & 8 & 11,0 & 19 & 26,0 & 27 & 37,0 & 19 & 26,0 & 73 & 100 \\
\hline
\end{tabular}

a: teratur, 6-8 jam sehari

b.tidak memenuhi kriteria pola tidur yang baik 
Tabel 4. Hubungan frekuensi mencuci wajah dengan kejadian akne vulgaris

\begin{tabular}{lcccccc}
\hline Frekuensi mencuci wajah & \multicolumn{5}{c}{ Kejadian Akne Vulgaris } \\
& \multicolumn{2}{c}{ Tidak ada-ringan } & \multicolumn{2}{c}{ Sedang - berat } & \multicolumn{2}{c}{ Total } \\
\hline & $\mathrm{N}$ & $\%$ & $\mathrm{n}$ & $\%$ & $\mathrm{n}$ & $\%$ \\
2-3x sehari & 35 & 49,3 & 36 & 50,7 & 71 & 100 \\
$<2 \mathrm{x}$ atau >3x sehari & 4 & 16,7 & 20 & 83,3 & 24 & 100 \\
Total & 39 & 41,1 & 56 & 58,9 & 95 & 100 \\
\hline
\end{tabular}

Hubungan mencuci wajah dengan kejadian akne vulgaris pada remaja laki-laki di Manado dianalisis dengan uji chi-square dan didapatkan $\mathrm{p}=0,004 \quad(<0,05)$ yang menunjukkan terdapat hubungan bermakna antara mencuci wajah dengan kejadian akne vulgaris pada remaja laki-laki di Manado.

\section{BAHASAN}

Hasil penelitian ini sejalan dengan penelitian yang dilakukan oleh Choi et al yang mendapatkan bahwa mencuci wajah sekali dalam sehari meningkatkan jumlah lesi, dan mencuci wajah dengan frekuensi empat kali dalam sehari tidak memperlihatkan perubahan lesi akne yang membaik, sedangkan mencuci wajah dua sampai tiga kali sehari mencapai lesi non-inflamasi yang jauh lebih rendah. ${ }^{6}$ Hasil penelitian ini juga selaras dengan penelitian yang dilakukan oleh Graha ${ }^{4}$ dan Hertanto ${ }^{7}$ yang mendapatkan hubungan bermakna antara personal hygiene kulit wajah dengan tingkat terjadinya akne vulgaris. Namun hasil penelitian ini berbeda dengan penelitian yang dilakukan oleh Kurniawati ${ }^{8}$ yang melaporkan tidak terdapat hubungan bermakna antara pengaruh kebersihan kulit wajah dengan kejadian akne vulgaris.

\section{SIMPULAN}

Terdapat hubungan bermakna antara frekuensi mencuci wajah dengan kejadian akne vulgaris pada remaja laki-laki di Manado.

Bagi masyarakat terutama usia remaja disarankan untuk membiasakan mencuci wajah yang baik dengan frekuensi 2-3 kali sehari menggunakan sabun pembersih wajah untuk mengurangi akne vulgaris.
Untuk penelitian selanjutnya, disarankan menggunakan rancangan penelitian yang lebih baik, populasi yang lebih besar, dan diagnosis langsung oleh dokter spesialis tanpa melalui foto. Selain itu, perlu diteliti faktor-faktor penyebab akne secara menyeluruh.

\section{Konflik Kepentingan}

Penulis menyatakan tidak terdapat konflik kepentingan dalam studi ini.

\section{DAFTAR PUSTAKA}

1. Sitohang IB, Wasitatmadja SM. Akne vulgaris. In: Linuwih, S, Menaldi, SW, Bramono, $\mathrm{K}$, Indriatmi, W, editors. Ilmu Penyakit Kulit dan Kelamin (7th ed). Jakarta: Badan Penerbit FKUI, 2015; p. 288-9.

2. Afriyanti RN. Akne vulgaris pada remaja. Jurnal Majority. 2015;4(6):10-7.

3. Sampelan MG, Pangemanan D, Kundre R. Hubungan timbulnya acne vulgaris dengan tingkat kecemasan pada remaja di SMP N 1 Likupang Timur. Jurnal Keperawatan. 2017;5(1):6.

4. Graha WP. Hubungan antara personal hygiene kulit wajah dengan tingkat terjadinya acne vulgaris di Pondok Pesantren AlMunawwir Yogyakarta. Surakarta: Universitas Muhammadiyah Surakarta; 2012.

5. Purwaningdyah RK. Profil penderita akne vulgaris pada siswa-siswi di SMA Shafiyyatul Amaliyyah Medan. E-jurnal Fakultas Kedokteran USU. 2009;1(1):2.

6. Hastuti R, Mustifah EF, Alya I, Risman M, Mawardi P. The effect of face washing frequency on acne vulgaris patients. J Gen Dermatology Venereology Indonesia. 2019;35-40.

7. Hertanto DC. Hubungan antara kebersihan wajah dengan kejadian akne vulgaris pada siswa SMA Negeri 3 Klaten. 
162 e-CliniC, Volume 8, Nomor 1, Januari-Juni 2020, hlm. 158-162

Surakarta: Universitas Muhammadiyah Surakarta; 2013.

8. Kurniawati AR. Pengaruh kebersihan kulit wajah terhadap kejadian acne vulgaris. Jurnal Media Medika Muda. 2014; 3(1):13. 